\title{
MENYUSUI DARI PERSPEKTIF SOSIAL DAN BUDAYA/CULTURE
}

\author{
FARADIBAH BAGENDA
}

\section{Universitas Islam Negeri Alauddin Makassar}

\section{Email : faradibahbagenda@gmail.com}

\section{PENDAHULUAN}

Faktor sosial budaya merupakan suatu faktor pendorong yang cukup kuat terhadap seseorang untuk berperilaku.Ibu menyusui perilaku budaya dimana tidak terlepas dari pandangan budaya yang telah diwariskan turun temurun dalam kebudayaan yang bersangkutan (Swaswono \& Meutia,1998).Organisasi Kesehatan Dunia (WHO) merekomendasikan ASI eksklusif sebagai strategi penting untuk mengurangi kematian anak, khususnya di negara berkembang. ASI eksklusif didefinisikan sebagai pemberian ASI kepada bayi tanpa disertai apapun bahan selain ASI untuk enam bulan pertama (tidak ada makanan atau cairan termasuk air).Dalam pembangunan bangsa, peningkatan kualitas manusia harus dimulai sedini mungkin yaitu sejak dini yaitu sejak masih bayi, salah satu faktor yang memegang peranan penting dalam peningkatan kualitas manusia adalah pemberian Air Susu Ibu (ASI).

Menyadari dan memiliki pemahaman yang lebih baik terhadap manfaat menyusui tidak berarti menyusui dipraktekkan seperti yang direkomendasikan Bahkan, angka menyusui di dunia masih sangat buruk. Ketika mengevaluasi praktek pemberian ASI eksklusif di 139 negara, Unicef menyampaikan temuan bahwa hanya 20\% dari negara-negara yang diteliti mempraktekkan pemberian ASI ekslusif pada lebih dari $50 \%$ bayi yang ada. Selebihnya, $80 \%$ dari negara-negara tersebut melakukan pemberian jauh lebih rendah dari 50\%.Indonesia dengan persentase pemberian ASI dipraktekkan pada 39\% dari seluruh bayi adalah salah satu dari negara yang tergolong kelompok $80 \%$ tersebut. Angka ini bahkan semakin parah karena penghitungan terbaru menunjukkan bahwa persentase Indonesia adalah jatuh lebih dari setengah angka di atas menjadi 15,3 persen dari seluruh bayi per tahun .

Praktek pemberian ASI diyakini menjadi salah satu masalah mendasar dari anak kurang gizi. WHO, sebagaimana dikutip oleh Unicef, mencatat bahwa 37\% dari anakanak Indonesia bertubuh kerdil, dan bahwa Indonesia menyumbang sebagai urutan kelima terbesar dalam jumlah anak yang pertumbuhannya terhambat di seluruh 
dunia.Pemberian ASI semaksimal mungkin merupakan kegiatan penting dalam pemeliharaan anak dan persiapan generasi penerus di masa depan.

Menurut Setio (dalam Nuryanto, 2002) bahwa ASI adalah suatu emulsi lemak dalam larutan protein laktosa dan garam-garam organik dengan komposisi lengkap dan sangat berguna sebagai makanan bayi. Nutrisi yang baik pada bayi akan membantu pertumbuhan dan perkembangan yang optimal selama beberapa bulan kehidupan bayi (Bobak dkk, 2004). ASI sebagai makanan yang terbaik bagi bayi tidak perlu diragukan lagi,namun akhir-akhir ini sangat disayangkan banyak diantara ibu-ibu meyusui melupakan keuntungan menyusui.Menurut Kemenkes RI (2014),secara nasional cakupan pemberian ASI ekslusif pada bayi 0-6 bulan berfluaktif dan belum mencapai target nasional 80\%, yaitu tahun 2012 sebesar 46,2\%, tahun 2013 sebesar 54,3\% dan tahun 2014 sebesar 52,3\%.

Selama ini dengan membiarkan bayi terbia samenyusui dari alat pengganti, padahal hanya sedikit bayi yang sebenarnya menggunakan susu botol atau susu formula. Kalau hal yang demikian terus berlangsung, tentunya hal ini merupakan ancaman yang serius terhadap upaya pelestarian dari peningkatan penggunaan ASI. Hingga saat ini akibat dari pemberian susu formula dan makanan tambahan menyebabkan kesakitan dan kematian pada bayi dan anak-anak. (Depkes RI, 2007). WHO (2008) menyatakan bahwa setiap tahun 1,5 juta anak balita meninggal dunia akibat penyakit diare yang sisebabkan susu formula, hal ini menyebabkan diare sebagai penyebab kematian terbesar kedua pada anak balita. Di negara ASEAN, anak-anak balita mengalami rata-rata 3-4 kali kejadian diare pertahun atau hampir 15-20\% waktu hidup anak dihabiskan untuk diare(Soebagyo, 2008).

\section{PANDANGAN SOSIAL BUDAYA TERHADAP ASI EKSLUSIF}

Jenis makanan prelakteal yang paling banyak diberikan kepada bayi baru lahir yaitu susu formula sebesar 79,8\%, madu $14,3 \%$, dan air putih $13,2 \%$ yang meliputi susu non formula, madu, air gula, air tajin, pisanghalus, kopi, teh manis, air putih, nasi halus, bubur halus. Makanan prelakteal ini sangat berbahaya jika diberikan terlalu dini kepada bayi karena tidak mengandung enzim sehingga penyerapan pada makanan akan tergantung pada enzim yang terdapat di usus bayi.

Menyusui merupakan salah satu dari sebagian kecil perilaku kesehatan positif yang lebih banyak dilakukan di Negara miskin daripada di Negara kaya. Dan 
menunjukkan bahwa perempuan miskin menyusui lebih lama daripada perempuan kaya. padahal seharusnya pemberian ASI untuk semua anak anak tanpa mempermasalahkan tempat tinggal mereka tergolong kategori kaya dan miskin.Menyusui yang benar dapat mencegah kejadian kesakitan pada anak karena dengan menyusui dapat memberikan ketahanan pada tubuh bayi (Victora et al., 2016).

Bayi yang diberi ASI Ekslusif sampai usia 6 bulan cenderung mempunyai anti bodi yang lebih dari bayi yang hanya disusui selama 4 bulan (Duijts \& Vincent,2017). Hak-hal yang diyakini oleh seseorang memegang peranan penting dalam pembuatan keputusan. Seperti juga halnya dalam pemberian ASI ekslusif, para ibu yang memberikan ASI secara ekslusif pada bayinya meyakini bahwa ASI memang yang terbaik untuk bayinya, selain itu mereka juga percaya bahwa ASI yang diberikan sudah mencukupi kebutuhan bayi. Berbeda dengan ibu yang tidak memberikan ASI ekslusif, walaupun beberapa dari mereka mengetahui tentang ASI ekslusif tapi nilai dan kepercayaan yang mereka anut masih sangat kental sehingga lebih dominan mempengaruhi keputusan.misalnya saja keyakinan mereka bahwa bayi yang sering menangis menandakan bahwa bayi masih lapar karena ASI yang mereka berikan belum cukup dan perlu ditambah dengan pembrian susu formula atau makanan tambahan lainnya. Memang di tempat penelitian banyak tradisi yang masih melekat pada masyarakat.

Bayi baru lahir sudah diberi makan pisang, diberi minum kopi dan sebagian dari mereka berpendapat selama mereka masih menyusui bayinya tidak jadi masalah kalau mereka memberikan susu formula atau makanan lain. Hal ini juga berkaitan dengan masih rendahmya pengetahuan yang mereka miliki tentang ASI ekslusif. Hasil penelitian yang dilakukan peneliti bahwa selama memberikan ASI Ekslusif adanya mitos tentang pembatasan makanan yang dimakan. Selama memberikan ASI Ekslusif tidak boleh makan pedas dan asam karena dapat menyebabkan bayi diare. Banyak minum es dapat menyebabkan anak sakit flu. Hal ini sejalan dengan hasil penelitian (Kumza \& Jerzy, 2013) bahwa sebanyak 57\% ibu mengakui adanya pembatasan makanan oleh budaya mereka.

Mitos-mitos yang terjadi di lingkungan sekitar juga mengatakan bahwa memberikan ASI Ekslusif akan membuat payudara menjadi tidak kencang berbeda dari sebelum melahirkan. Faktanya bahwa payudara menjadi tidak kencang disebabkan oleh 
bertambahnya usia dan kehamilan. Pada saat hamil, hormon-hormon menambah kelenjar ASI sehingga membuat ukuran payudara lebih dari ukuran biasanya. Ketika masa menyusui usia, ukuran payudara akan kembali menjadi normal sehingga mengendur (tidak kencang) (Yuliarti \& Nurbeti,2010)

Berdasarkan hasil pengujian hubungan faktor budaya dengan keberhasilan pemberian ASI Eksklusif dengan uji fisher exact diperoleh signifikasi perhitungan lebih kecil dari 0,05 yaitu 0,004. Sehingga dapat disimpulkan bahwa ada hubungan antara sosial budaya dengan pemberian ASI Eksklusif.

Hasil penelitian ini didukung oleh penelitian yang dilakukan Elvayanie (2003) di Kalimantan Selatan menyatakan bahwa posisi inisiasi ASI berhubungan dengan tingkat pengetahuan, faktor psikologis dan faktor kebiasaan atau kepercayaan yang mendasari soasil budaya. Banyaknya kebiasaan dan kepercayaan masyarakat mengenai pantangan untuk tidak makan-makanan yang amis (ikan, telur, ayam) dan kepercayaan bahwa kolostrum merupakan cairan yang kotor mendasari banyaknya ibu menyusui di wilayah Kalimantan Selatan tidak memberikan ASI Eksklusif kepada anaknya.

Pemberian ASI tidak lepas dari tatanan budaya. Artinya setiap pemberian ASI dari ibu kepada anaknya akan berhubungan dengan sosial budaya yang ada dimasyarakat. Perilaku dibentuk oleh kebiasaan yang diwarnai oleh sosial budaya. Setiap orang selalu terpapar dan tersentuh oleh kebiasaan lingkungan serta mendapat pengaruh dari masyarakat, baik secara langsung maupun tidak langsung (Perinasia, 2003). Perilaku yang telah dibentuk dengan oleh kebiasaan dan kepercayaan akan pemberian ASI Eksklusuif akan berdampak pada keingingan ibu untuk memberikan ASI Eksklusif kepada anak. Sosial budaya ini akan mempengaruhi keberhasilan pemberian ASI Eklusif, responden yang memiliki kategori sosial budaya baik akan menunjukan keberhasilan dalam pemberian ASI Eksklusif. Hal ini ditunjukan dengan $25(45,5 \%)$ responden memiliki kategori sosial budaya yang baik dengan pemberian ASI Eksklusif.

Menteri Negara Pemberdayaan Perempuan berpendapat, faktor sosial budaya ditandai menjadi faktor utama pada pemberian ASI eksklusif pada balita di Indonesia. Ketidaktahuan masyarakat, gencarnya promosi susu formula, dan kurangnya fasilitas tempat menyusui di tempat kerja dan publik menjadi kendala utama. Seharusnya tidak ada alasan lagi bagi seorang ibu untuk tidak menyusui bayinya, faktor sosial budaya 
berupa dukungan suami terhadap pemberian ASI eksklusif menjadi faktor kunci kesadaran sang ibu untuk memberikan gizi terbaik bagi bayinya.

Tidak sedikit bayi baru berumur dua bulan sudah diberi makanan pendamping karena ketidaktahuan ibu terhadap manfaat ASI. Berdasarkan riset yang sudah dibuktikan di seluruh dunia, ASI merupakan makanan terbaik bagi bayi hingga enam bulan, dan disempurnakan hingga umur dua tahun (Media Indonesia, 2008).

Kepercayaan sering atau diperoleh dari orang tua, kakek atau nenek. Seseorang menerima keperayaan itu berdasarkan keyakinan dan tanpa adanya pembuktian terlebih dahulu (Notoatmodjo, 2003). Kepercayan seseorang terhadap hal tersebut tergantung dari kuatnya kepercayaan yang diturunkan oleh nenek moyang dan pengalaman yang dimiliki.

Menurut Hatta (2007) mitos-mitos ataupun kepercayaan merupakan hambatan untuk tindakan menyusui yang normal, diantaranya:(a)Kolostrum tidak baik bahkan bahaya untuk bayi. (b) Bayi membutuhkan teh khusus atau cairan lain sebelum menyusui. (c) Bayi tidak mendapatkan cukup makanan atau cairan bila hanya diberi kolustrun atau ASI. Sebagian ibu percaya bahwa bayi membutuhkan banyak makanan dan cairan untuk pertumbuhannya, sehingga sseorang ibu akan berusaha memberikan makanan selain ASI untuk mencukupi kebutuhan tersebut.

Kebiasaan minum jamu merupakan salah satu faktor sosial budaya yang menandakan adanya keinginan sehat (Yany, 2012). Keyakinan ini hendaknya dapat didorong dengan lebih memotivasi pentingnya makanan bergizi dan seimbang bagi ibu hamil dan menyusui, pentingnya memelihara payudara ibu sebelum melahirkan untuk persiapan ASI bagi bayinya. Kebiasaan minum jamu ini mendorong ibu untuk makan sehat sehingga produksi ASI semakin bertambah banyak. Volume ASI yang bertambah banyak ini yang mendorong ibu untuk memberikan ASI.

\section{HUBUNGAN KEPERCAYAAN DAN TRADISI KELUARGA PADA IBU YANG SEDANG MENYUSUI DALAM PEMBERIAN ASI EKLUSIF}

Penelitian ini memaparkan praktik pemberian makanan prelakteal yang masih dilakukan seperti pada bayi baru lahir diberikan air gula merah, air kopi, madu hutan, dan atau santan kental. Pada ibu yang melahirkan dipelayanan kesehatan biasanya makanan prelakteal yang diberikan adalah susu formula. Ibu-ibu yang melahirkan 
hanya sebagian kecil yang melakukan IMD, praktik pemberian makanan prelakteal ini berdampak negatif terhadap program ASI eksklusif. Para informan menyatakan pemberian makanan prelakteal ini saran dari orang tua dan orang-orang di sekitar ibu.

Penelitian faktor sosial budaya di Karawang pada tahun 2002, menjelaskan bahwa hal-hal yang mendorong sebagian besar ibu untuk memberikan ASI adalah karena naluri sebagai wanita yang baru melahirkan, merupakan kodrat, rasa tanggung jawab atau kewajiban, dorongan kasih sayang kepada anak, dan karena kondisi ekonomi. Sebagian kecil lainnya mengatakan karena dorongan orang tua dan bidan atau paraji.Disini tampak bahwa dorongan dari diri sendiri atau ibu cukup besar pengaruhnya dalam pemberian ASI [4].

Penelitian di Kabupaten Bone Provinsi Sulawesi Selatan pada tahun 2013, menunjukkan bahwa secara statistik tidak terdapat hubungan bermakna antara sikap responden dengan pemberian ASI eksklusif. Para responden umumnya memiliki kemauan untuk memberikan ASI eksklusif, namun akan dihentikan dengan mudah ketika menemui kendala [5]. Kendala yang dihadapi oleh para ibu yang ditemui dalam penelitian ini adalah pada hari-hari pertama setelah melahirkan, ASI tidak keluar dengan lancar, kesulitan memosisikan bayi atau ASI tidak keluar sama sekali.

Penelitian di Kanigoro, Blitar tahun 2013 menghasilkan bahwa diberikan perlakuan seperti penyuluhan dapat memberikan perubahan sikap dari individu. Pengetahun Ibu mengenai ASI eksklusif mempengaruhi sikap ibu. Ada faktor lain juga yang mempengaruhi selain pengetahuan yaitu faktor sosial budaya yang menjadi faktor lain pembentuk sikap ibu.

Penelitian Satino (2014) di Kota Surakarta, menjelaskan bahwa faktor lingkungan yang mendukung pemberian ASI eksklusif dan lingkungan yang tidak mendukung pemberian ASI esklusif. Hal ini menunjukkan bahwa faktor lingkungan berpengaruh positif terhadap pemberian ASI eksklusif. Lingkungan merupakan kondisi yang ada di sekitar manusia dan mempengaruhi perkembangan dan perilaku orang atau kelompok

Penelitian Sopiyani (2014) di Kabupaten Klaten, menemukan ada hubungan positif yang sangat signifikan antara dukungan sosial dengan motivasi memberikan ASI eksklusif. Artinya,semakin tinggi (kuat) dukungan sosial maka akan tinggi pula motivasi dalam memberikan ASI eksklusif. 
Tradisi yang dilakukan responden saat menyusui pertama kali yaitu memberi kegunaan pada keadaan bayi dimana bayi saat lahir diberi madu untuk mengeluarkan lendir karena menelan air ketuban serta asam untuk daya tahan tubuh. Hal ini juga didukung dengan lebih dominan dipengaruhi oleh orang tua atau mertua.

Pemberian madu maupuan asam secara dini pada bayi baru lahir atau disebut makanan prelakteal seperti susu, madu, air kelapa, pisang, air tajin dan air nasi berbahaya karena makanan ini dapat menggantikan kolostrum dan bayi mungkin dapat terkena diare, septisemia dan meningitis, serta akan menghilangkan rasa haus bayi sehingga bayi malas menyusui (Kementerian Kesehatan RI, 2014)

\section{DUKUNGAN SOSIAL DARI SUAMI DALAM PEMBERIAN ASI EKSLUSIF}

Di Indonesia, budaya dan ideologi patriarki masih sangat kental mewarnai berbagai aspek kehidupan dan struktur sosial masyarakat dan memengaruhi aspek masyarakat dalam berinteraksi7. Patriarki adalah sistem pengelompokan masyarakat sosial yang mementingkan garis keturunan bapak/laki-laki. Patrilineal adalah hubungan keturunan melalui garis keturunan kerabat pria atau bapak. Patriarki juga dapat dijelaskan dimana keadaan masyarakat yang menempatkan kedudukan dan posisi lakilaki lebih tinggi dari pada perempuan dalam segala aspek kehidupan sosial, budaya dan ekonomi .

Dalam perspektif gender, budaya patriarki menjadi budaya yang bertolak belakang dimana dominansi pria semakin besar membuat peran perempuan termarginalkan oleh peran laki-laki dalam keluarga, terutama dalam monopoli proses pengambilan keputusan.

Budaya patriarki dapat dikaitkan dengan peran yang dominan dari seorang suami selaku ayah dalam rumah tangga. Dominansi ayah dalam memberikan input positif berupa dorongan bagi anggota keluarganya dapat dilihat dalam praktik pemberian ASI ekslusif. Melalui dukungan dan penguatan dalam memengaruhi aksi ibu dalam pemberian ASI, yang didasari ikatan-ikatan patrilinealistik.

Banyak faktor yang menjadi masalah pemberian ASI yang rendah di Indonesia, salah satu faktor pendukung adalah suami, yang merupakan orang terdekat yang memainkan peran kunci selama kehamilan, persalinan dan setelah bayi lahir termasuk 
pemberian ASI4. Di Australia, praktek pemberian ASI eksklusif terbukti 1,5 kali lebih berhasil apabila didukung oleh suami.

Angka keberhasilan menyusui bayi sampai 6 bulan meningkat pada kelompok studi yang mengikut sertakan ayah dan ibu dalam konseling menyusui dibanding kelompok studi yang hanya diikuti oleh ibu. Dukungan keluarga bagi ibu yang memadai secara signifikan terkait dengan praktik pemberian ASI eksklusif .

Hal ini konsisten dengan penelitian yang menunjukkan bahwa dukungan keluarga dapat meningkatkan secara signifikan pencapaian ASI ekslusif. Anggota keluarga dapat meningkatkan kepatuhan ibu dalam menyusui eksklusif dengan menekankan bahwa ASI menyediakan sumber nutrisi tertinggi untuk bayi. Untuk memberikan dukungan kepada ibu, suami dan nenek atau keluarga lainnya bisa berkontribusi pada pengasuhan anak, menyediakan penitipan anak, membeli atau menyiapkan makanan, dan memberi makan anak-anak.

Dukungan keluarga juga dapat meningkatkan kepercayaan diri ibu, sebuah studi kualitatif di Myanmar telah menyoroti bahwa para ibu memerlukan dukungan ayah karena ayah juga dapat membantu dalam mendapatkan informasi tentang menyusui selain memberikan dorongan dan motivasi.

Lima peran utama untuk dukungan suami adalah pengetahuan, sikap positif, keterlibatan dalam pengambilan keputusan, praktis dukungan, dan dukungan emosional untuk menyusui. Sikap positif atau negatif suami terhadap menyusui dapat mempengaruhi perilaku menyusui ibu. Sikap negatif yang dipengaruhi oleh preferensi seksual, seperti ketakutan bahwa menyusui akan merusak bentuk payudara, dapat menyebabkan suami tidak menyetujui menyusui. Selain itu, sikap positif suami dipengaruhi ketika ekonomi rumah tangga menguntungkan menyusui.

Seorang ayah dapat memberikan dukungan yang positif untuk meningkatkan praktik pemberian ASI, dan mempertahanankan dukungan penuh kepada istri dalam memberikan ASI sampai bayi berusia 6 bulan untuk mencapai ASI ekslusif . Misalnya suami bisa membantu istri menyelesaikan pekerjaan rumah ketika istri sedang menyusui, suami dapat ikut menyendawakan bayi setelah selesai menyusui, membantu ibu menyusui saat ditempat umum dengan mengeluarkan kain menyusui, suami dapat menemani istri datang ke kelas-kelas laktasi, memberikan asupan gizi yang cukup 
kepada ibu untuk memperlancar ASI, mengingatkan istri untuk selalu memberikan ASI saja sampai usia bayi 6 bulan

Mengambil peran positif dalam budaya patriarki, memberikan kesempatan bagi seorang suami selaku ayah bagi untuk bertanggung jawab dalam memberikan dukungan dan motivasi kepada ibu bayi agar sukses mencapai ASI ekslusif. Ketidak seimbangan gender dalam konsep patriarki membuat ayah menjadi dominan dalam memberikan dukungan emosional kepada ibu bayi. Sehingga meskipun ibu bayi kurang termotivasi dengan ASI ekslusif, tetapi dengan seorang suami yang mempunyai pandangan positif tentang hal tersebut dapat merubah aksi dari seorang ibu. 


\section{DAFTAR PUSTAKA}

dr.Nurhira Abdul Kadir, MPH. Menelusuri Akar Masalah Rendahnya Presentase Pemberian Asi Ekslusif Di Indonseia . Vol.XV Nomor 1/2014, 107118.

Fikki Prasetya, A. Y. (2019, juni). Budaya Patriarki Dalam Praktik Pemberian ASI Eksklusif. Volume 03 | Nomor $01 \mid$ JUNI | 2019, 3, 4547.

Ningsih, D. A. (2018, april selasa). FAKTOR-FAKTOR YANG MEMENGARUHI PEMBERIAN ASI. Volume 9 Nomor 2, April 2018, 9, 110113.

Oktova, R. (2017, november). Analisis Faktor yang Berhubungan dengan Pemberian Susu Formula. Volume VIII, Nomor 3, November 2017, 315-320.

Rosmiati, M. S. (2020). Tradisi Ibu Menyusui Dengan Pemberian Asi Ekslusif Di Lingkungan Pesisir Pada Wilayah Kerja Puskesmas Pomalaa Dengan Pendektana Entnografi. vol 5(3) Oktober 2020, (487-495).

Alam, S., and Syahrir, S. (2016).Faktor-Faktor yang Berhubungan Dengan TeknikMenyusui pada Ibu di Puskesmas Pattallassang Kabupaten Takalar8, $130-138$

Alam, S., and Syahrir, S. (2017) Hubungan Personal Hygiene Pemberian SusuFormula Dengan Kejadian Diare Pada Bayi di Kelurahan Dannuang Kecamatan Ujung Loe Kabupaten Bulukumba Tahun 2016.Higenial : Jurnal KesehatanLingkungan3, 77-86.

Alam, S., \& Karini, T. A. (2020). Islamic Parenting" Pola Asuh Anak: TinjauanPerspektif Gizi Masyarakat" 